\title{
In vivo measurements of the seasonal photosynthetic fluorescence of the Mediterranean coral Cladocora caespitosa (L.)
}

\author{
ANDREA PEIRANO \\ ENEA - Marine Environment Research Center, C.P. 224, I-19100 La Spezia, Italy. E-mail: peirano@ santateresa.enea.it
}

\begin{abstract}
SUMMARY: In situ photosynthetic fluorescence of the zooxanthellate Mediterranean coral Cladocora caespitosa (L.) was measured seasonally on colonies from 5 to $27 \mathrm{~m}$ depth using an INF-300 Integrating Natural Fluorometer (Biospherical Instrument Inc.). This oceanographic instrument, used to measure the in vivo phytoplankton chlorophyll a (Chl a) fluorescence, was adapted to record the natural fluorescence of C. caespitosa by SCUBA divers. The resulting curves of natural fluorescence of Chl a vs photosynthetically active radiation (PAR 400-700 nm) showed that: (1) natural fluorescence was limited by light availability in both deep and shallow colonies in all seasons; (2) photosynthesis occurred in C. caespitosa also in winter, when temperature is low and seawater turbidity contributes significantly to PAR attenuation; and (3) the efficiency of the $\mathrm{Chl}$ a fluorescence increased from summer to winter. This last finding outlines the winter coupling between zooxanthellae activity and calcification processes and is consistent with the formation of the high density band in the coral skeleton.
\end{abstract}

Keywords: coral, Mediterranean Sea, in vivo fluorescence, photosynthesis.

RESUMEN: MEDIDAS IN VIVO DE LA FLUORESCENCIA FOTOSINTÉTICA ESTACIONAL EN EL CORAL MEDITERRÁNEO CLADOCORA CAESPITOSA (L.). - La fluorescencia fotosintética in situ, de las zooxantelas del coral mediterraneo Cladocora caespitosa (L), se determinó estacionalmente sobre colonias desde 5 a 26 m de profundidad a través de un fluorimetro integrador INF-300 (Biospheral Instrument Inc.). Este instrumento oceanográfico, utilizado para medir la fluorescencia de la clorofilla a del fitoplancton in vivo, se ha adaptado para determinar la fluorescencia natural de C. caespitosa por los buceadores. Las curvas resultantes de la fluorescencia natural de la clorofila a vs la radiación (PAR 400-700 nm) fotosintéticamente activa mostraban que: la fluorescencia natural estaba limitada por la disponibilidad de luz en ambas colonias de profundidad y de aguas poco profundas en todas las estaciones del año, (2) la fotosíntensis producida en C. caespitosa tenia lugar también en invierno, cuando la temperatura es baja y la turbidez del agua contribuyen de forma significativa a la atenuación de PAR, (3) la eficiencia de la fluorescencia de la clorofila a incrementaba desde verano a invierno. Este último hallazgo pone de manifiesto el acoplamiento entre la actividad de las zooxantelas y los procesos de calcificación y es consistente con la formación de la banda de alta densidad en el esqueleto coralino.

Palabras clave: coral, mar Mediterráneo, fluorescencia in vivo, fotosíntesis.

\section{INTRODUCTION}

Cladocora caespitosa (L.) is a scleractinian coral living in the Mediterranean Sea from 5 to $40 \mathrm{~m}$ depth in turbid environments (Laborel, 1961; Zibrowius, 1980). Large fossil C. caespitosa formations have been dated since the Late Pliocene and characterised the warmer climatic phases of the Pleistocene when this coral formed true reefs in both the eastern and western Mediterranean Sea (Peirano et al., 2004). Today C. caespitosa forms extensive shallow-water 'beds' of colonies with densities up to $4 \mathrm{col} \mathrm{m}^{-2}$ or massive banks covering several square metres (Peirano et al., 2001; Kružic and Požar-Domac, 2004). 
The coral has a phaceloid form with separated corallites growing upward. Sclerochronology studies revealed that C. caespitosa deposits two bands per year with annual growth rates ranging from 1.36 to $4.42 \mathrm{~mm} \mathrm{yr}^{-1}$ and no differences were found in either the timing of band deposition or growth rates between shallow and deep colonies (Peirano et al., 1999). The low-density band is deposited during the dry, hot summer (June-September). In autumn (October-November) the coral begins the deposition of the high density band, which is fully developed in March, at the end of the winter, a season characterised by rain, low sea water temperature and rough sea (Peirano et al., 2005).

In winter $\mathrm{C}$. caespitosa lives in such a turbid environment (less than $6 \mathrm{~m}$ water transparency measured with the Secchi disk) that it is hard to believe that, both in shallow water and at depth, photosynthesis can even occur, let alone contribute to the coral's growth.

Although some tropical species react to cooler water temperature and lower PAR with the enhancement of chl contents and zooxanthellatae densities (Warner et al., 2002), Cladocora caespitosa did not show seasonal variation of the photosynthetic apparatus (Schiller, 1993; Rodolfo-Metalpa et al., 2006).

In the present work the seasonal, photosynthetic activity of the coral was verified through measurements of in vivo natural fluorescence, as the fluorescent flux from the chlorophyll a stimulated by the available sunlight. Natural fluorescence of $\mathrm{Chl}$ a, which was proved to be related to Chl a content, was measured on shallow and deep colonies and compared within seasons and depths and with the band deposition pattern of the coral.

\section{MATERIAL AND METHODS}

Dives between 5 and $27 \mathrm{~m}$ were carried out along the eastern Ligurian coast (northwestern Mediterranean), where beds and banks of Cladocora caespitosa are common (Peirano et al., 1999). Two sampling sites were located in front of the Magra River (FM), at $5 \mathrm{~m}$ depth, and $1 \mathrm{~km}$ apart at Punta Bianca (PB), at $10 \mathrm{~m}$ depth. Three more sites were positioned at 10,20 and $40 \mathrm{~km}$ to the west of the Magra River, down current: 1) Cala Grande (CG), where C. caespitosa colonies are limited to $20 \mathrm{~m}$ depth; 2) Capo di Montenero $(\mathrm{MN})$, with one deep bank at $27 \mathrm{~m}$ depth and rare,

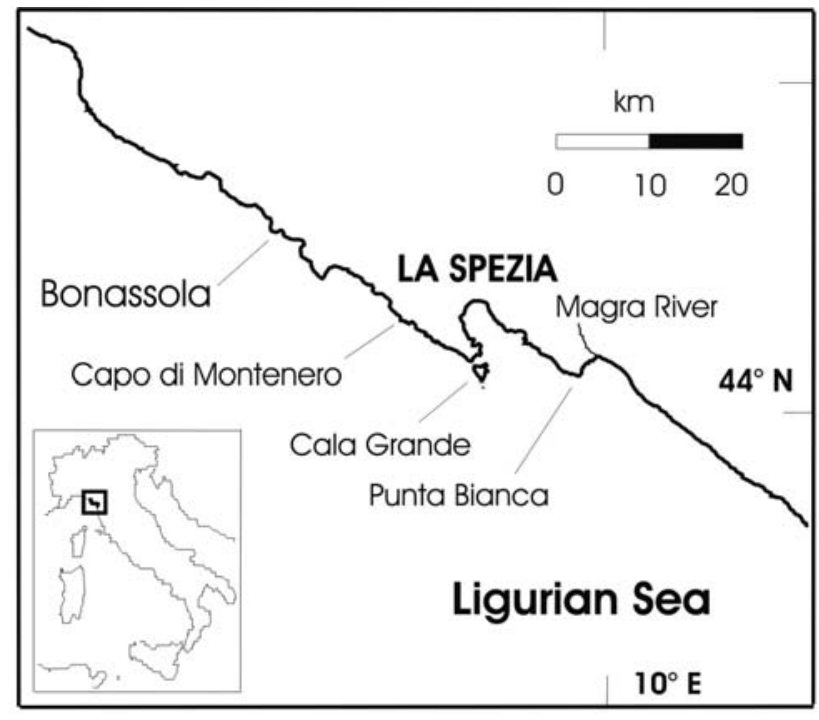

FIG. 1. - Coastal region of La Spezia and sampling sites: Bonassola (BO), Capo di Montenero (MN), Cala Grande (CG), Punta Bianca (PB) and the mouth of the Magra River (FM).

sparse colonies at $17 \mathrm{~m}$; and 3) Bonassola (BO), with shallow coral beds at 7 and $9 \mathrm{~m}$ depth and one deep bank at $27 \mathrm{~m}$ depth (Fig. 1).

Natural chlorophyll a (Chl a) fluorescence was measured using an INF-300 Integrating Natural Fluorometer (Biospherical Instrument Inc.), a device used to measure in vivo phytoplankton fluorescence (Chamberlin et al., 1990). The system has a detector arranged to record natural upwelling radiance of a water mass, filtering the emission spectra of $\mathrm{Chl}$ a and rejecting wavelengths of less than $650 \mathrm{~nm}$. The INF-300 also measures the scalar irradiance of underwater photosynthetically active radiation (PAR, 400 to $700 \mathrm{~nm}$ ), depth and water temperature and has an internal memory that allows continuous recording of data at a rate of up to 1 record per second.

To adjust the probe to measure $\mathrm{Chl}$ a fluorescence of C. caepistosa the sensitivity of the $\mathrm{Chl}$ a sensor was first tested in aquaria at constant temperature and light $\left(\mathrm{T}=20^{\circ} \mathrm{C}\right.$, PAR $=60 \mu \mathrm{E} \mathrm{m}{ }^{-2}$ $\mathrm{sec}^{-1}$ ). Measurements were made both on phytoplankton monoculture of Dunaliella sp. and on one C. caespitosa colony positioned at a distance of 10 $\mathrm{cm}$ below the fluorescence sensor. The in vivo phytoplankton fluorescence measurements showed a highly significant positive correlation with increasing Chl a contents from a minimum of $0.88 \mu \mathrm{g} \mathrm{l}^{-1}$ Chl a $\left(\mathrm{N}=14, \mathrm{R}^{2}=0.989, \mathrm{P}<0.0001\right)$. The in vivo measurements of $\mathrm{C}$. caespitosa fluorescence performed on C. caespitosa showed that the measurements were significantly related to the increasing 
number of corallites $\left(\mathrm{N}=8, \mathrm{R}^{2}=0.995, \mathrm{P}<0.0001\right)$ from a minimum of 23 corallites, corresponding to a surface of $9 \mathrm{~cm}^{2}$.

To normalise underwater fluorescence measurements to a preset surface area, a black panel with one circular window with a radius of $4.1 \mathrm{~cm}(52.8$ $\mathrm{cm} 2$ ) was fixed at a distance of $10 \mathrm{~cm}$ below the fluorescence sensor. The coefficient of attenuation of the exciting irradiance $(\mathrm{k})$, i.e. the attenuation of the fluorescence signal vs the distance from the window sensor was $\mathrm{k}=1.12$.

Underwater measurements on C. caespitosa were carried out on days with clear sky and flat sea between 11.00 am and 1.00 pm GMT. Sampling was performed in autumn 1999 (October-November), in summer 2000 (August-September), and in winter 2001 (February). Above water, downwelling PAR irradiance was recorded with a ThetaLog Delta-T device connected to a flat sensor. During diving operations the INF-300 was positioned on top of coral colonies or on different areas of coral banks to record the total natural fluorescence (Fn). After each recording sequence the diver closed the window with a mobile black sheet to measure the natural fluorescence of the water mass between the sensor and the colony $(\mathrm{Fw})$. Hence the fluorescence of the coral $(\mathrm{Fc})$ in $\mu \mathrm{mol} \mathrm{cm} \mathrm{cm}^{-2}$ was obtained from the relationship $\mathrm{Fc}=(\mathrm{Fn}-\mathrm{Fw}) * \mathrm{k}$. The fluorescence per polyp $(\mathrm{Fp})$ in $\rho$ mol polyp ${ }^{-1}$ was calculated as $\mathrm{Fp}=\mathrm{Fc} / \mathrm{Np}$, where $\mathrm{Np}$ was the total number of polyps counted in the window.

Fp differences between colonies and differences between seasonal curves of Fp versus underwater PAR irradiance were analysed through analysis of covariance (ANCOVA), with PAR as a covariate, and Tukey post-hoc comparisons of means. Homogeneity of variances was checked with Levene's test.

\section{RESULTS}

During underwater measurements atmospheric PAR irradiance varied between a minimum of 200 $500 \mu \mathrm{mol} \mathrm{m} \mathrm{m}^{-2} \mathrm{~s}^{-1}$ in October-February to a maximum of $1100-1500 \mu \mathrm{mol} \mathrm{m} \mathrm{m}^{-2} \mathrm{~s}^{-1}$ in August-September. Sea water temperature in autumn and winter was uniform from shallow to $30 \mathrm{~m}$ depth $\left(22^{\circ} \mathrm{C}\right.$ in October and November, $14^{\circ} \mathrm{C}$ in February). In summer, when stratification occurs, water temperatures varied from $26^{\circ} \mathrm{C}$ at surface to $20^{\circ} \mathrm{C}$ at $30 \mathrm{~m}$ depth.
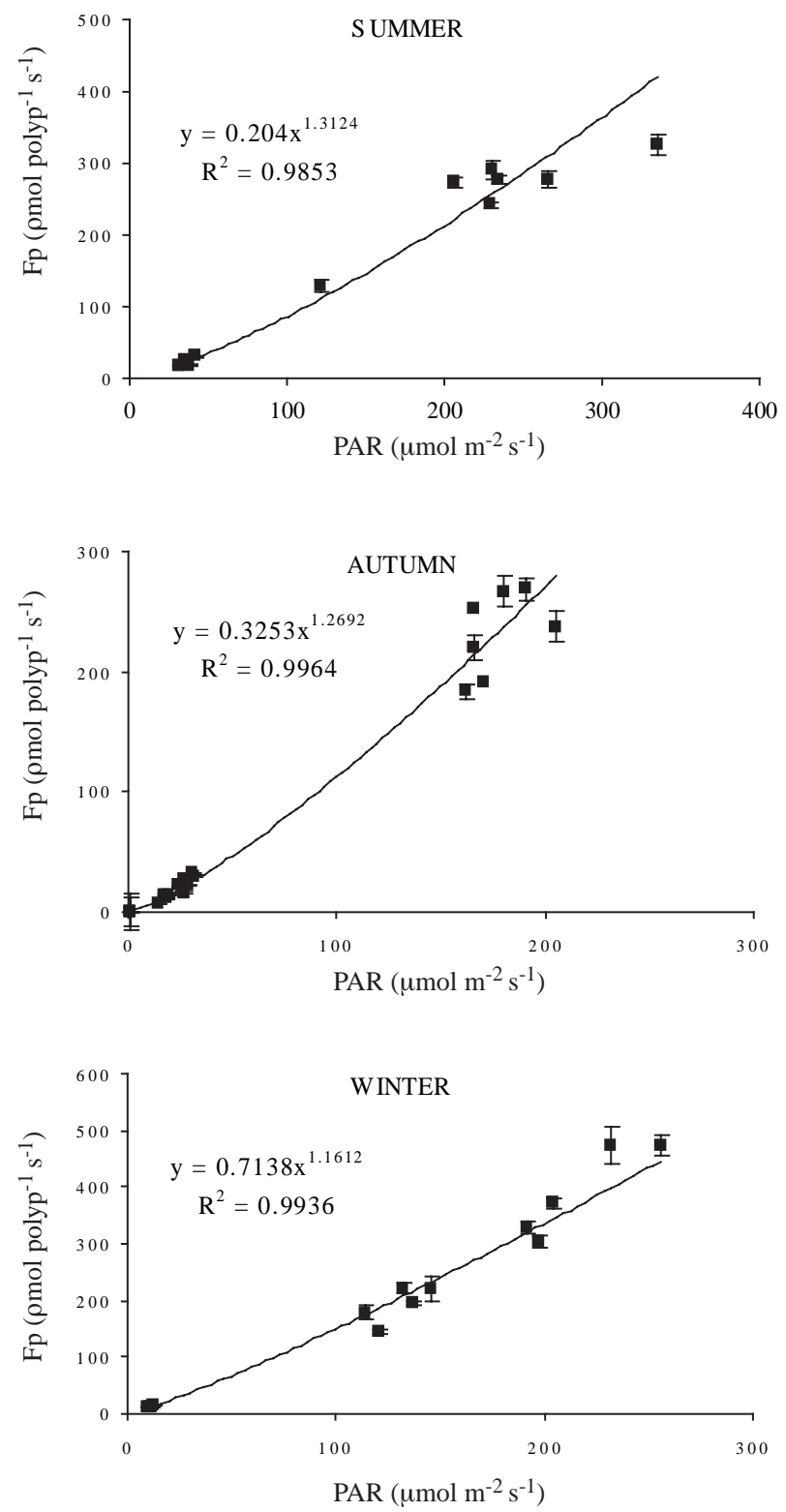

FIG. 2. - Cladocora caespitosa. Seasonal natural $\mathrm{Chl}$ a fluorescence per polyp (Fp) vs underwater PAR irradiance.

In the three seasons investigated $\mathrm{C}$. caespitosa showed polyp fluorescence (Fp) exponentially related to PAR $\left(\mathrm{R}^{2}>0.988 ; \mathrm{P}>0.05\right)$ (Fig. 2).

Differences observed in each season between and within sites were related to water turbidity that, in some cases, limited light availability considerably. For example, Fp measurements made in autumn (Table 1) on C. caespitosa colonies living near the river mouth, at $9 \mathrm{~m}$ depth (PB14-PB18) ranged from 15.7 to 32.5 omol polyp $^{-1}$, values comparable with those measured on the same day, at $20 \mathrm{~m}$ depth, on Cala Grande colonies CG1-CG5 (6.6-21.9 $\mathrm{\rho mol}$ polyp $\left.^{-1}\right)$. Again, the comparison of Fp measurements 
TABLE 1. - Mean values of in vivo natural fluorescence of chlorophyll a per polyp (Fp) (maximum and minimum in parenthesis) and mean photosynthetically active radiation (PAR) measured with INF-300 probe on Cladocora caespitosa colonies in the three seasons (sd = standard deviation). Sites: $\mathrm{CG}=$ Cala Grande; $\mathrm{PB}=$ Punta Bianca; FM = Magra River; $\mathrm{Mn}=$ Capo di Montenero; $\mathrm{BO}=\mathrm{Bonassola}$.

\begin{tabular}{|c|c|c|c|c|c|c|c|}
\hline Season & Colony & Depth (m) & $\operatorname{PAR}\left(\mu \mathrm{mol} \mathrm{m}{ }^{-2} \mathrm{~s}^{-1}\right)$ & PAR (sd) & $\mathrm{Fp}\left(\rho \mathrm{mol} \mathrm{pol}^{-1}\right)$ & $\mathrm{Fp}(\mathrm{sd})$ & $\mathrm{n}$ \\
\hline \multirow[t]{12}{*}{ Summer } & CG1 & 20 & 31.0 & 3.9 & $18.4(15.7-22)$ & 2.1 & 55 \\
\hline & CG2 & 20 & 31.5 & 1.4 & $17.2(15.3-18.7)$ & 0.9 & 55 \\
\hline & CG3 & 20 & 41.4 & 1.9 & $30.1(27-32.8)$ & 1.7 & 60 \\
\hline & CG4 & 20 & 35.8 & 4.7 & $25.5(21.1-29.8)$ & 3.1 & 56 \\
\hline & CG5 & 20 & 37.8 & 1.4 & $18.5(16.7-20.4)$ & 1.1 & 63 \\
\hline & PB 1 & 9 & 206.0 & 3.2 & $273.6(262.4-292.5)$ & 7.8 & 50 \\
\hline & PB2 & 9 & 228.8 & 4.9 & $242.3(232.5-253.9)$ & 4.6 & 77 \\
\hline & PB3 & 9 & 234.5 & 4.1 & $276.8(257.8-290.5)$ & 5.9 & 78 \\
\hline & PB4 & 9 & 265.7 & 6.5 & $277.2(250.5-302.6)$ & 11.7 & 87 \\
\hline & PB5 & 9 & 230.0 & 9.9 & $290.6(238.7-319.6)$ & 13.6 & 124 \\
\hline & MN1 & 27 & 121.3 & 3.4 & $128.6(104.3-142.6)$ & 8.5 & 135 \\
\hline & MN2 & 17 & 334.0 & 25.0 & $325.4(293.9-372.9)$ & 15.1 & 77 \\
\hline \multirow[t]{22}{*}{ Autumn } & CG1 & 20 & 17.3 & 0.7 & $14.0(13.7-14.5)$ & 0.2 & 44 \\
\hline & CG2 & 20 & 14.6 & 0.8 & $6.6(5.6-8.3)$ & 0.7 & 69 \\
\hline & CG3 & 20 & 19.3 & 0.7 & $14.2(12.9-15)$ & 0.5 & 61 \\
\hline & CG4 & 20 & 18.4 & 0.4 & $11.2(10.4-11.8)$ & 0.4 & 71 \\
\hline & CG5 & 20 & 24.3 & 0.5 & $21.9(21-22.5)$ & 0.5 & 37 \\
\hline & CG6 & 20 & 0.6 & 0.03 & $0.2(0.1-0.2)$ & 0.02 & 79 \\
\hline & CG7 & 20 & 0.6 & 0.03 & $0.2(0.1-0.2)$ & 0.02 & 113 \\
\hline & CG8 & 20 & 0.6 & 0.02 & $0.2(0.1-0.2)$ & 0.01 & 90 \\
\hline & CG9 & 20 & 0.6 & 0.03 & $0.2(0.1-0.2)$ & 0.01 & 104 \\
\hline & CG10 & 20 & 0.5 & 0.02 & $0.1(0.1-0.2)$ & 0.01 & 90 \\
\hline & PB14 & 9 & 31.1 & 0.7 & $32.5(31.1-33.7)$ & 0.6 & 40 \\
\hline & PB15 & 9 & 31.9 & 0.5 & $29.4(28.1-30.4)$ & 0.6 & 52 \\
\hline & PB16 & 9 & 26.8 & 0.3 & $15.7(14.2-16.5)$ & 0.5 & 51 \\
\hline & PB17 & 9 & 28.5 & 0.7 & $21.9(19-23.7)$ & 1.1 & 63 \\
\hline & PB18 & 9 & 27.2 & 0.7 & $26.9(25.3-28.5)$ & 0.8 & 57 \\
\hline & FM7 & 5 & 204.8 & 5.6 & $237.7(210.7-254.2)$ & 11.3 & 69 \\
\hline & FM8 & 5 & 161.5 & 8.6 & $183.2(150.3-205.1)$ & 15.8 & 42 \\
\hline & FM9 & 5 & 190.7 & 2.0 & $268.5(235.7-291.7)$ & 13.2 & 52 \\
\hline & FM10 & 5 & 180.2 & 2.3 & 266.7 (252.7-272.6) & 5.1 & 59 \\
\hline & FM11 & 5 & 166.2 & 3.1 & $219.9(192.5-237.1)$ & 10.1 & 54 \\
\hline & FM12 & 5 & 170.4 & 4.6 & $191.4(160.5-219.6)$ & 13.5 & 58 \\
\hline & FM13 & 5 & 166.3 & 4.3 & $252.8(210.2-262.6)$ & 10.4 & 61 \\
\hline \multirow{14}{*}{ Winter } & $\mathrm{BO} 1$ & 27 & 9.9 & 0.1 & $10.5(10.1-11)$ & 0.2 & 32 \\
\hline & $\mathrm{BO} 2$ & 27 & 10.1 & 0.3 & $10.5(8.6-12)$ & 1.0 & 67 \\
\hline & BO3 & 27 & 11.1 & 0.2 & $10.1(9.6-10.5)$ & 0.2 & 57 \\
\hline & $\mathrm{BO} 4$ & 27 & 12.3 & 0.2 & $15.8(14.2-16.5)$ & 0.4 & 80 \\
\hline & BO5 & 9 & 145.7 & 3.0 & $220.5(179.8-253.1)$ & 22.9 & 65 \\
\hline & BO6 & 9 & 137.5 & 1.9 & $194.5(188.8-199.9)$ & 2.8 & 67 \\
\hline & BO7 & 9 & 132.3 & 2.0 & $222.1(204.1-235.7)$ & 10.2 & 54 \\
\hline & $\mathrm{BO} 8$ & 9 & 114.4 & 2.6 & $178.8(160.1-195.7)$ & 11.4 & 54 \\
\hline & BO9 & 9 & 120.7 & 1.2 & $144.1(138.4-147.7)$ & 2.5 & 42 \\
\hline & BO10 & 7 & 204.1 & 3.9 & $372.1(347.2-386.4)$ & 9.0 & 77 \\
\hline & BO11 & 7 & 191.3 & 4.7 & $328.0(303.8-343.4)$ & 11.3 & 35 \\
\hline & $\mathrm{BO} 12$ & 7 & 231.8 & 0.7 & $473.2(432-519.8)$ & 32.9 & 28 \\
\hline & BO13 & 7 & 255.6 & 19.5 & $474.1(433.4-516.6)$ & 17.2 & 47 \\
\hline & BO14 & 7 & 197.3 & 2.7 & $302.8(283.7-319.9)$ & 10.2 & 54 \\
\hline
\end{tabular}

made in autumn at Cala Grande on two different days (CG1-CG5 vs CG6-CG10) showed significant differences $(\mathrm{P}<0.05)$ due to seawater turbidity, which one day severely reduced underwater irradiance and caused a fall in chlorophyll fluorescence in CG6-CG10 colonies (Table 1).

In general western colonies (Montenero and Bonassola) proved to live in an environment characterised by less turbidity than eastern ones (Cala Grande, Punta Bianca and Foce Magra). This was also true in summer, when fluorescence measured on colonies CG1-CG5 at Cala Grande at $20 \mathrm{~m}$ depth
(17.2-30.1 omol polyp $\left.^{-1}\right)$ was significantly lower $(\mathrm{P}<0.0001)$ than $\mathrm{Fp}$ values recorded at $27 \mathrm{~m}(\mathrm{MN} 1$; 128.6 omol polyp $\left.{ }^{-1}\right)$ and $17 \mathrm{~m}(\mathrm{MN} 2 ; 325.4$ omol polyp $\left.{ }^{-1}\right)$ depth at Punta di Montenero.

The continuous recording of natural fluorescence throughout a day performed in September on the MN1 bank of Punta di Montenero (Fig. 3) was used to calculate the exponential curve $\mathrm{Fp}=0.9088 \mathrm{PAR}$ $1.0644(\mathrm{R} 2=0.999 ; \mathrm{P}>0.05)$. The curve did not differ from the autumn curve of Figure $2(\mathrm{P}>0.05)$, showing that deep colonies of Cladocora caespitosa have the same fluorescence activity as shallow ones. 


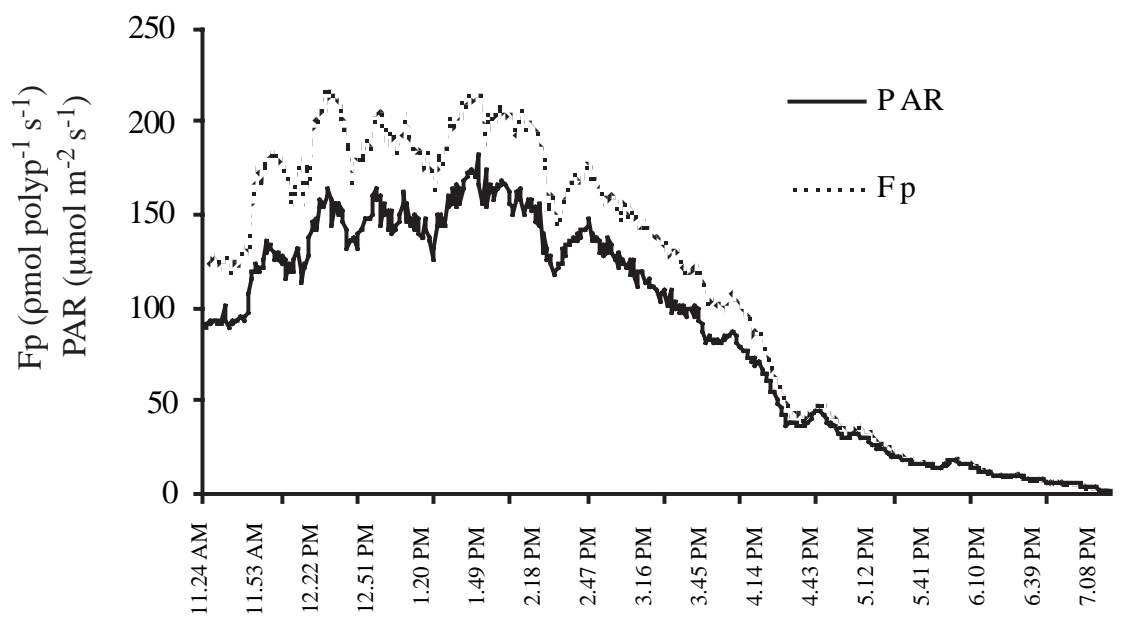

Hours

FIG. 3. - Cladocora caespitosa. Continuous recording of in vivo Chl a fluorescence per polyp (Fp) vs underwater PAR irradiance at Capo di Montenero (MN1, $27 \mathrm{~m}$ depth, September).

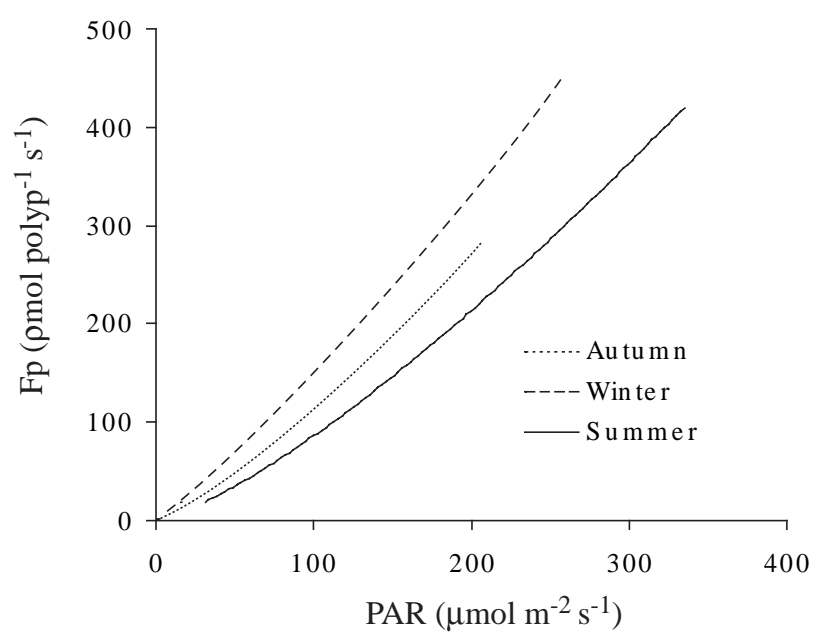

FIG. 4. - Cladocora caespitosa. Comparison between seasonal curve of Chl a fluorescence per polyp vs underwater PAR irradiance.

The comparison of the three seasonal curves of Fp vs PAR showed that the Chl a natural fluorescence of $\mathrm{C}$. caespitosa differed significantly $(\mathrm{P}<0.0001)$ from summer to winter (Fig. 4), with an increase in efficiency in autumn and winter, seasons characterised by rough sea, low temperature and low light availability.

\section{DISCUSSION}

The INF-300 was used to perform non-intrusive measurements of active photosynthesis in extreme, natural dim conditions without sample manipulation or incubation which, as pointed out by Sakshaug et al. (1997), may affect final data. Though the evalua- tion of true photosynthetic yield from INF-300 measurements proved to be very difficult (Chamberlin et al., 1990; Maritonema et al., 1990), the measurements on Cladocora caespitosa confirmed that photosynthesis occurs in the coral even in winter months, when turbidity may reduce light penetration to a minimum.

C. caespitosa showed natural fluorescence that was variable in both depth and season, and no photoinibition effects were observed. The findings allow us to assume that colonies of C. caespitosa have photosynthetic $\mathrm{Chl}$ a fluorescence limited seasonally only by light availability. Chl a fluorescence was light-limited in deep colonies and the efficiency of fluorescence increased from summer to winter, when available light is lower. Though the true photosynthetic yield of $\mathrm{C}$. caespitosa could not be calculated from INF-300 fluorescence measurements, such findings are in accordance with oxigen-flux measurements conducted by Schiller (1993) on colonies kept at constant temperatures, with the seasonal fluctuations of the photosynthetic capacity of Indo-Pacific corals found by Brown et al. (1999), and with higher values of photosynthetic yield measured in periods of cooler water temperature and lower PAR on the Caribbean species of Montastrea (Warner et al., 2002).

The increase of natural fluorescence efficiency in autumn and winter supports the hypothesis of the active coupling of zooxanthellae and polyp metabolism toward the enhancement of the calcification processes. This is consistent with the formation of the high-density (HD) band in more than $50 \%$ of C. caespitosa colonies in autumn and in all the colonies in 
winter (Peirano et al., 1999). On the other hand, the lowest values of natural fluorescence recorded in summer are in agreement with the formation of the low-density bands (LD). The summer is indeed a season when C. caespitosa is subjected to stress due to periods of high irradiance, high temperature and starvation that may cause the onset of tissue necrosis (Peirano et al., 2005; Rodolfo-Metalpa et al., 2005).

Though the photosynthetic fluorescence of deep colonies is lower than that of shallow ones throughout the year, the absence of differences in growth rates between shallow and deep colonies found by Peirano et al. (1999) remains difficult to explain. Whereas in tropical corals this homogeneity is achieved through the increase in zooxanthellae and/or chlorophyll contents in deeper colonies (Stimson, 1997; Brown et al., 1999; Titlyanov et al., 2001; Warner et al. 2002), in C. caespitosa zooxanthellae contents do not change significantly between shallow and deep colonies and during the year (Schiller, 1993). Some specific biochemical adaptations could be hypothesised in deep colonies to explain growth rates similar to shallow water colonies as being due to the enhanced utilization of carbon sources, a reduction of respiration to photosynthesis ratio or changes in enzyme activities (Barnes and Chalker, 1990; Muscatine, 1990; Warner et al., 2002). Colonies in a shaded environment may balance photosynthesis limitations, enhancing the polyp's active feeding, which-as Houlbrèque et al. (2003) demonstrated on the tropical coral Stylophora pistillata-contributes to the improvement of calcification processes. In C. caespitosa this strategy is consistent with the winter availability of POM and DOM from resuspended sediments (Peirano et al., 2005) and with the parallel increase in plankton, which attains its maximum in this season in the northwestern Mediterranean (Goffart et al., 2002).

Hence, C. caespitosa allows one to hypothesise complex environmental adaptations that explain its past and current success in colonising the Mediterranean. Though further research is needed, the results show that a great part of the coral's 'flexibility' is due to its photosynthetic apparatus, which is adapted to react to the extreme variability of underwater irradiance of the Mediterranean. In tropical corals light limitation may severely reduce the photosynthetic yield of zooxanthellae-coral complex (Yentsch et al., 2002) and related reactions, as the increase in density of zooxanthellae and/or pho- topigments require hours or days to be achieved (Falkowski et al., 1990; Dunne and Brown, 2001). On the other hand, C. caespitosa shows a constant chlorophyll content and number of zooxanthellae (Schiller, 1993; Rodolfo-Metalpa et al., 2006), allowing one to hypothesise the enhancement of the PSII system efficiency as the quickest way to adapt to underwater irradiance variability.

\section{ACKNOWLEDGEMENTS}

I am grateful to $\mathrm{M}$. Abbate and R. Rodolfo Metalpa for their help in laboratory measurements and to $\mathrm{S}$. Cocito and anonymous referees for the critical reading of the manuscript. I also wish to thank my colleagues S. Sgorbini, C.N. Bianchi, and D. Ferrari of the "Punta Mesco" Diving Centre for their assistance during diving operations.

\section{REFERENCES}

Barnes, D.J. and B.E. Chalker. - 1990. Calcification and photosynthesis in reef-building corals and algae. In: Z. Dubinski (ed.), Ecosystem of the world 25 - Coral Reefs, pp. 109-130. Elsevier, New York

Brown, B.E., R.P. Dunne, I. Ambarsari, M.D.A. Le Tissier, and U. Satapoomin. - 1999. Seasonal fluctuations in environmental factors and variations in symbiotic algae and chlorophyll pigments in four Indo-Pacific coral species. Mar. Ecol. Prog. Ser., 191: 53-69.

Chamberlin, W.S., C. Booth, D.A. Kiefer, J.H. Morrow and R.C. Murphy. - 1990. Evidence for a simple relationship between natural fluorescence, photosynthesis and chlorophyll in the sea. Deep-Sea Res., 37(6): 951-973.

Dunne, R.P. and B.E. Brown. - 2001. The influence of solar radiation on bleaching of shallow water reef corals in the Andaman Sea, 1993-1998. Coral Reefs, 20: 201-210.

Falkowski, P.G., P.L. Jokil, and R.A. Kinzie III. - 1990. Irradiance and corals. In: Z. Dubinski (ed.), Ecosystem of the world 25 Coral Reefs, pp. 89-108. Elsevier, New York.

Goffart, A., J-H. Hecq and L. Legendre. - 2002. Changes in the development of the winter-spring phytoplankton bloom in the Bay of Calvi (NW Mediterranean) over the last two decades: a response to changing climate? Mar. Ecol. Prog. Ser., 236: 45-60.

Houlbrèque, F., E. Tambutté and C. Ferrier-Pagès. - 2003. Effects of zooplankton availability on the rates of photosynthesis, and tissue and skeletal growth in the scleractinian coral Stylophora pistillata. J. Exp. Mar. Biol. Ecol., 296: 145-166.

Kružic, P. and A. Požar-Domac. - 2004. Banks of the coral Cladocora caespitosa (Anthozoa, Scleractinia) in the Adriatic Sea. Coral Reefs, 22(4): 536.

Laborel, J. - 1961. Sur un cas particulier de concrétionnement animal. Concrétionnement à Cladocora caespitosa (L.) dans le Golfe de Talante. Rapp. p-v Reun. CIESM 16(2): 429-432.

Maritonema, S., A. Morel and B. Gentili. - 2000. Determination of the fluorescence quantum yield by oceanic phytoplankton in their natural habitat. Appl. Opt., 39(36): 6725-6737.

Muscatine, L. -1990 . The role of symbiotic algae in carbon and energy flux in reef corals. In: Z. Dubinski (ed.), Coral Reefs, pp. 75-88. Elsevier, New York

Peirano, A., C. Morri and C.N. Bianchi. - 1999. Skeleton growth and density pattern of the zooxanthellate scleractinian Cladocora caespitosa (L.) from the Ligurian Sea (NW 
Mediterranean). Mar. Ecol. Prog Ser., 185: 195-201.

Peirano, A., C. Morri, C.N. Bianchi, and R. Rodolfo-Metalpa. 2001. Biomass, Carbonate Standing Stock and Production of the Mediterranean Coral Cladocora caespitosa (L.). Facies, 44: 75-80.

Peirano, A., C. Morri, C.N. Bianchi, J. Aguirre, F. Antonioli, G. Calzetta, L. Carobene, G. Mastronuzzi and P. Orru'. - 2004. The Mediterranean coral Cladocora caespitosa: a proxy for past climate fluctuations? Global Planet. Change, 40: 195-200.

Peirano A., M. Abbate, G. Cerrati, V. Difesca, C. Peroni, and R. Rodolfo-Metalpa. - 2005. Monthly variations in calix growth, polyp tissue, and density banding of the Mediterranean scleractinian Cladocora caespitosa (L.). Coral Reefs, 24: 404-409.

Rodolfo-Metalpa R., C.N. Bianchi, A. Peirano and C. Morri. 2005. Tissue necrosis and mortality of the temperate coral Cladocora caespitosa. Ital. J. Zool., 72: 271-276.

Rodolfo-Metalpa R., Richard C., Allemand D., Bianchi C.N., Morri C., Ferrier-Pagès - 2006. Response of zooxanthellae in symbiosis with the Mediterranean corals Cladocora caespitosa and Oculina patagonica to elevated temperatures. Mar. Biol., 150: 45-55.

Schiller, C. - 1993. Ecology of the symbiotic coral Cladocora caespitosa (L.) (Faviidae, Scleractinia) in the Bay of Piran (Adriatic Sea): II. Energy budget. PSZNI: Mar. Ecol., 14(3): 221-238.

Shakshaug, E., A. Bricaud, Y. Dandonneau, P.G. Falkowski, D.A Kiefer, L. Legendre, A. Morel, J. Parslow and M. Takahashi. -
1997. Parameters of Photosynthesis: definitions, theory and interpretation of results. J. Plankton Res., 19 (11): 1637-1670. Sorokin, Y. - 1995. Coral reef ecology. Ecological studies 102. Springer-Verlag, Berlin.

Stimson, J. - 1997. The annual cycle of density of zooxanthellae in the tissue of field and laboratory-held Pocillopora damicornis (Linneus). J. Exp. Mar. Biol. Ecol., 214: 35-48.

Titlyanov, E.A., T.V., Titlyanova, K. Yamazato and R. van Woesik. - 2001. Photo-acclimation dynamics of the coral Stylophora pistillata to low and extremely low light. J. Exp. Mar. Biol. Ecol., 263: 211-225.

Warner, M.E. G.C. Chilcoat, F.K. Mc Farland and W.K. Fitt. 2002. Seasonal fluctuations in the photosynthetic capacity of photosystem II in symbiotic dinoflagellates in the Caribbean reef-building coral Montastrea. Mar. Biol., 141: 31-38.

Zibrowius, H. - 1980. Les Scléractiniaires de la Méditerranée et de l'Atlantique nord-oriental. Mem. Inst. Oceanogr. (Monaco), 11: $1-284$.

Yentsch, C.S., C.M. Yentsch, J.J. Cullen, B. Lapointe, D.A. Phinney and S.W. Yentsch. - 2002. Sunlight and water transparency: cornerstones in coral research. J. Exp. Mar. Biol. Ecol., 268: 171-283.

Scient. ed.: P.J. López-González.

Received March 7, 2006. Accepted May 22, 2007.

Publised online September 3, 2007. 